\title{
The Realization of Brown's Theory of Assessing Reading on Reading Section of English National Examination
}

\author{
Zahratun Nufus ${ }^{l}$ \\ Nur Ifadloh ${ }^{2}$ \\ ${ }^{1}$ English Education Department, STAI Rasyidah Khalidiyah Amuntai, Indonesia; zahratun918@gmail.com \\ ${ }^{2}$ English Education Department, STAI Rasyidah Khalidiyah Amuntai, Indonesia; ifadloh@ gmail.com
}

\begin{tabular}{lll}
\hline Received: July 18, 2021 & Accepted: July 29, 2021 & Published: July 29, 2021
\end{tabular}

\begin{abstract}
This study is concerned with the realization of Brown's theory of assessing reading on the English national examination. This study focused on the English national examination for junior high schools in the academic year 2018/2019. It aimed to know what types of assessing reading were used and what the most dominant types were used on the English national examination based on the realization of Brown's theory. The qualitative approach was employed. The method of analysis used was descriptive research. Based on the data analysis, there was only one type of the four types of reading assessment which was implemented on the English national examination. It was interactive reading. The tasks which were used in interactive reading are impromptu reading plus comprehension question as many as 49 questions which are included in 17 texts and ordering tasks as many as 1 question which was included into 1 text. All of them were spread into 17 texts. The most dominant type of assessing reading was interactive reading (50 questions) which consisted of 49 questions of impromptu reading plus comprehension questions and 1 question of ordering tasks.
\end{abstract}

Keywords: Assessing reading; English national examination; Junior High Schools.

To cite this article: Nufus, Z., \& Ifadloh, N. (2021). The realization of Brown's theory of assessing reading on reading section of English national examination. SALEE: Study of Applied Linguistics and English Education, 2(02), 182-191. https://doi.org/10.35961/salee.v2i02.288 


\section{Introduction}

Reading is one of language skills that must be mastered by the students in junior high school. It becomes very important skill because most formal tests use the written words as a stimulus for test-takers' response; even oral interviews perhaps entail reading performance for certain tasks. Thus, it can be stated that reading arguably becomes the most essential skill for success in the educational contexts.

Reading remains a skill of paramount importance as we create assessments of general language ability. The assessment of reading ability does not end with the measurement of comprehension (Brown, 2004, p.185). Further, Brown (2004, p.185) explains that strategic pathways to full understanding often become important factors that must be included in assessing learners, especially in the case of most classroom assessments that are formative in nature. Here, test-takers need to improve their strategies to comprehend the texts that they are facing. Those strategies are very important to make them reach good comprehension. For example, a student may be able to understand an academic technical report at the sentence level, but if he has not exercised certain strategies for noting the discourse conventions of that genre, misunderstanding may occur (Brown, 2004, p.185).

In reading test, there are many things that must be considered by us, such as the components of reading ability, a number of different types or genres of written texts and specific tasks that are commonly used in the assessment of reading (Brown, 2004, p.186). However, we must not forget that the nature of reading has something that cannot be observed. For example, someone cannot see the process of reading, nor can one observe a specific product of reading. It is because there is no technology that enables us to see sequences of graphic symbols travelling from the pages of a book into compartments of the brain (in a possible bottom-up process). Even, there is no one that can watch information from the brain make its way down onto the page (in typical top-down strategies). All assessment of reading must be carried out by inference (Brown, 2004, p.186).

One of assessment which has ever existed in Indonesia is National Examination (abbreviated into NE). NE becomes the latest form of a school leaving examination in Indonesia starting from 2005 until 2020. It can be defined as a test to measure and evaluate the students' competence nationally by the central government after the process of teaching and learning (The Regulation of the Minister of Education, 2005). The NE is implemented as a way of improving national education quality, which is supported by Government Regulation Number 19 year 2005 on the National Standards of Education. Based on the Law of the Republic of Indonesia Number 20 year 2003, the NE is done in order to control the quality of education nationwide to be evaluated as a form of accountability of education providers to the parties concerned. Furthermore, it stated that the evaluations conducted by independent agencies on a regular basis, comprehensively, transparently, and systematically to assess the achievement of national education standards and the monitoring process evaluation should be done continuously. Evaluation of the monitoring process is carried out continuously and continuous in the end will be able to fix the quality of education. However, the government has recently changed their policy to stop holding NE in 2020 until now to avoid the spread of Corona Virus Disease 2019 (abbreviated into Covid 19) (Yuilyana, 2020). The pandemic of Covid 19 absolutely becomes the biggest barrier for Education field in Indonesia since we cannot study face to face at school. The study should be held via online learning and not all many people are ready to study via online. However, it must not make researchers, educators and policy makers silent and not want to make a progress. This must be turning point to make our education better than before.

Improving reading scores needs a concerted and collaborative effort by researchers, educators, and policy makers with a focus on long-term solutions (Elleman and Oslund (2019, 
p.3). In Indonesia, reading still becomes big problem, especially for the students. It is obviously correct since the Indonesian people reading habit is very low (Mustafa, 2012). That is why researches related to improving students' skill in reading comprehension are often conducted (Putri, et al., 2019; Al Aziz \& Yusanti, 2020; Ahmada, 2020; Rijal \& Rohaniyah, 2020; Rombot, et al., 2020). Nevertheless, the study about analysis of reading assessment related to the way test makers create the questions of reading section still gets less attention. That is why this study want to observe the reading assessment on the reading section of English national examination which ever became the standard test for English subject in Indonesia so that we can know the type of questions which is frequently made in the reading section of English National Examination. By knowing the type of the frequently questions which appears in the test, the teachers can determine the best strategy to teach reading class so that it can help the students find the best way to study about reading comprehension. In this study, brown's theory is used to observe reading assessment on the reading section of English national examination.

Based on the explanation above, this study aimed to know what types of assessing reading were used on the English national examination for junior high schools in the academic year 2018/2019 and what the most dominant types were used on the English national examination for junior high schools in the academic year 2018/2019 based on the realization of Brown's theory. Hopefully, this study could give an evaluation for question makers of the English Test for junior high school so that they could equally include appropriate reading types for the students.

\subsection{Nature of Reading}

There are various definitions of reading which are presented by some experts. According to Celce-Murcia (2001, p.154), reading is a complex cognitive process of decoding symbols in order to construct or derive meaning (reading comprehension). It becomes a means of language acquisition, of communication, and of sharing information and ideas. Furthermore, Urquhart \& Weir (1998, p.22) say that reading is the process of receiving and interpreting information encoded in language form via the medium of print. It can be seen that reading becomes a complex interaction between the text and the reader. Through the medium of print, the authors want to deliver the information while the readers are expecting to get the true information from the authors. However, in this process, the messages of the text are shaped by the reader's prior knowledge, experiences, attitude, and language community which are culturally and socially situated. Therefore, reading becomes an activity which involves the reader and the text in that the reader tries to comprehend the messages.

Goodman as cited in Carrel, et al. (2012, p.2) points out that reading is a receptive language process. It becomes a psycholinguistic process in that it starts with a linguistic surface representation encoded by a writer and ended by meaning which the reader construct. There is thus an essential interaction between language and thought as language and reader decode language to thought.

In addition, Linse (2005, p.69) claims that reading is a set of skills that involves making sense and deriving meaning from the printed words. That is why the reading process requires continuous practice, development, and refinement. In reading process, there will be the writer's intension and the reader's interpretation. The writer puts the meaning of the text through printed or written verbal symbols. Then, the reader will interpret what is meant by the writer.

Furthermore, reading entails creativity and critical analysis. It can be stated like that that since consumers of literature should make ventures with each piece, innately deviating from literal words to draw images that make sense to them in the unfamiliar places the texts describe. Reading cannot be controlled or restricted to one or two interpretations as reading is such a complex process. There are no concrete laws in reading, but rather allows readers an escape to 
produce their own products introspectively. This promotes deep exploration of texts during interpretation. Readers use a variety of reading strategies to assist with decoding (to translate symbols into sounds or visual representations of speech) and comprehension. Readers may use context clues to identify the meaning of unknown words. Readers integrate the words they have read into their existing framework of knowledge or schema (schemata theory).

\subsection{Types of Assessing Reading}

In the case of reading, variety of performance is derived more from the multiplicity of types of texts than from the variety of overt types of reading performance are typically identified, and this will serve as organizers of various assessment tasks. According to Brown (2004, p.189), there are four types of assessing reading. Each of reading types has different kind of exercises. The explanation will be described as follows:

\subsubsection{Perceptive Reading}

Perceptive reading is the very basic level of reading. The learner is in the early stage of becoming literate. Perceptive reading tasks involve attending to the components of larger stretches of discourse: letters, words, punctuation, and other graphemic symbols. Bottom-up processing is implied. At the beginning level of reading a second language, the fundamental tasks include: recognition of alphabetic symbols, capitalized and lowercase letters, punctuation, words, and grapheme-phoneme correspondences. They are referred to as "literacy" tasks, implying that the learner is in the early stages of becoming 'literate'. Items include 1) Reading aloud; 2) Written response; 3) Multiple-Choice; and 4) Picture-Cued Items.

Perceptive reading requires students to process separate letters, words, punctuation, and other graphemic symbols of larger stretches of discourse (Brown, 2004). An example of a very basic grapheme recognition task would require students to decipher differences in similar words. This assessment tests for the students' understanding of simple graphemic characters. Another example of a perceptive reading assessment would be to match pictures with the corresponding words.

\subsubsection{Selective Reading}

If perceptive reading is the basic level of reading, selective reading is a little bit expanding. A selective task is to ascertain one's reading recognition of lexical, grammatical, or discourse features of language within a very short stretch of language items such as picture-cued tasks, matching, true/false, multiple-choice, etc. Expected answers include sentences, brief paragraphs, simple charts and graphs, and brief responses as well. A combination of bottom-up and top-down processing may be both used to assess lexical and grammatical aspects of reading ability. Items include: 1) Multiple-Choice (form-focused criteria); 2) Matching Tasks; 3) Editing tasks; 4) Picture-cued tasks; and 5) Gap-filling tasks.

Selective reading requires students to recognize lexical, grammatical, or discourse features of language within a very short text (a sentence, a brief paragraph, or a simple chart or graph) (Brown, 2004). The following example necessitates the students to prove their comprehension of 20 short statements. The students read one statement at a time and choose the answer that has the same meaning as the statement. Another example of a selective reading assessment is the following multiple-choice cloze vocabulary/grammar task. Sometimes multiple items can be grammatically correct but not contextually correct so students need to focus on the form and context of what they are reading in order to select the correct response.

\subsubsection{Interactive Reading}

In interactive reading, reading is considered as a process of negotiating meaning; the reader brings to the text a set of schemata for understanding it, and intake is the product of that 
interaction. The focus of an interactive task is to identify relevant features (lexical, symbolic, grammatical, and discourse) within texts of moderately short length with the objective of retaining the information that is processed. Typical genres that lend themselves to interactive reading are anecdotes, short narratives and descriptions, excerpts from longer texts, questioners, memos, announcements, directions, recipes, and the like. Top-down processing is typical of such tasks with occasional use of bottom-up skills. Tasks at this level, like selective tasks, have a combination of form-focused and meaning-focused objectives but with more emphasis on meaning. Texts are a little longer, from a paragraph to as many as a page or so in case of ordinary prose. Charts, graphs, and other graphics may be somewhat complex in their format. Tasks include: cloze tasks, multiple choices for reading comprehension, short answer questions, editing tasks, scanning, ordering tasks, and non-verbal tasks for information transfer such as charts, maps, graphs, and diagrams.

Interactive reading can require students to read several paragraphs to one page of text or more and psycho-linguistically interact with the text (negotiate meaning) to identify relevant features and retain information that is conceptually processed (Brown, 2004).

One such example entails a paragraph about autumn and multiple-choice comprehensioncheck questions following the passage. This would be good for ESL students in the beginning stages of interactive reading. Another way of assessing students' interactive reading abilities is to have them read cloze passages and fill in expected prepositions or conjunctions. This can pose grading difficulties if there are multiple possibilities, but does aid the learner overall in the area of prediction of prepositions or conjunctions.

\subsubsection{Extensive Reading}

Extensive reading applies to texts of more than one page up to and including professional articles, essays, technical reports, short stories, and books (it should be noted that reading research commonly refers to "extensive reading" as longer stretches of discourse, such as long articles and books that are usually read outside a classroom hour, here that definition is massaged a little in order to encompass any text longer than a page). Global understanding is the aim for assessment. Top-down processing is assumed for most extensive tasks. Skimming tasks are to get the main ideas; summarizing (a synopsis or overview of the text) and responding (personal opinion on the test as a whole). Note-taking and outlining are both used frequently for the higher-ordered learning. But tasks like short-answers, editing, scanning, ordering, and information transfer tasks can also be used to assess extensive reading. Extensive reading requires students to read articles, essays, technical reports, short stories, or books in order to assess global understanding of a text rather than the understanding of minute details (Brown, 2004, p.212).

A very common example of an extensive reading assessment is to have students summarize long texts. Skimming tasks are also used for extensive reading assessments. These tasks have good washback potential because they require multiple stages of thought (pre-reading, postreading, in-class discussions, and comprehension checks.

\section{Method}

In this study, qualitative approach was employed to identify the realization of Brown's theory of assessing reading on the English national examination for junior high schools in the academic year 2018/2019. It was used since interpretation and description of the information about this study involved in analyzing the data. Moreover, the data were presented in the form of words or pictures rather than numbers.

The method of this research used in this study was descriptive research. According to Polit and Hungler (1999), descriptive research is a type of research that describes what exist and may 
help to uncover new facts and meaning. These studies are a means of discovering new meaning, describing what exists, documenting aspects of a situation, determining the frequency with which something occurs, and categorizing information.

The statement above can be noted that a qualitative-descriptive research is a method which is used to give some information by describing the study in detail. Therefore, it easily gets a better understanding of the data. Furthermore, Polit and Hungler (1999) state that the purpose of descriptive research is to observe, describe, and document aspects of a situation as it naturally occurs. It means that descriptive research plays an important role in the study. The message can be received accurately and comprehensively when the description is clearly explained in the study. It is one of the best ways for the researcher to use a descriptive research to make the study completely understandable and to hinder a misunderstanding.

\subsection{Instruments}

The data were taken from the English national examination for junior high schools in the academic year 2018/2019. There were seventeen texts which contain fifty questions. In order to collect information, the data were analyzed based on Brown's theory.

\subsection{Data Analysis}

In analyzing the data, all of questions in reading section were selected, compared, and interpreted whether or not they were included the realization of the theory. Firstly, the data were selected by taking all questions in the English national examination for junior high schools in the academic year 2018/2019. Then, all of questions in this exam were compared with Brown's theory. The last, the data were analyzed by giving such interpretation of the questions in reading section of the English national examination for junior high schools in the academic year 2018/2019.

\section{Finding and Discussion}

Based on analyzing the data, the result showed that Brown's theory of assessing reading was truly realized on the English national examination for junior high schools in the academic year 2018/2019. However, among four types of assessing reading, there was only one type of assessing reading used on the reading section of the English national examination. It was interactive reading, meanwhile the other types were not found at all. In interactive reading, there were two kinds of interactive design assessment tasks realized in this exam. They were impromptu reading plus comprehension question and ordering task. To make them clear, all of them were summarized in the following Table 1:

Table 1. Types of Assessing Reading

\begin{tabular}{cccc}
\hline No. & Types of Reading & Total \\
\hline 1. & Perceptive & Reading aloud & 0 \\
& (Number of Texts) & Written Response & 0 \\
& & Multiple Choice & 0 \\
& & Picture-Cued Items & 0 \\
\hline 2. & Selective & Multiple Choice (for Form-Focused Criteria) & 0 \\
& (Number of Texts) & Matching Tasks & 0
\end{tabular}




\begin{tabular}{|c|c|c|c|}
\hline & & Editing Tasks & 0 \\
\hline & & Picture-Cued Tasks & 0 \\
\hline & & Gap-Filling Tasks & 0 \\
\hline \multirow[t]{7}{*}{3.} & Interactive & Cloze Tasks & 0 \\
\hline & (Number of Texts) & $\begin{array}{c}\text { Impromptu Reading Plus Comprehension } \\
\text { Questions }\end{array}$ & 49 (17 texts) \\
\hline & & Short-Answer Tasks & 0 \\
\hline & & Editing (Longer Tasks) & 0 \\
\hline & & Scanning & 0 \\
\hline & & Ordering Tasks & $1(1$ text $)$ \\
\hline & & $\begin{array}{c}\text { Information Transfer: Reading Charts, Maps, } \\
\text { Graphs, Diagrams }\end{array}$ & 0 \\
\hline \multirow[t]{4}{*}{4.} & Extensive & Skimming Tasks & 0 \\
\hline & (Number of Texts) & Summarizing & 0 \\
\hline & & Responding & 0 \\
\hline & & Note-Taking and Outlining & 0 \\
\hline
\end{tabular}

Based on the table above, it shows that there was only one type that was implemented on this exam. It was interactive reading. The tasks which were used in interactive reading were impromptu reading plus comprehension questions and ordering tasks. They were used in 17 texts that consisted of 50 questions. The impromptu reading plus comprehension questions were used in 49 questions which were included in all texts. Then, ordering tasks were used only in 1 question which was included in 1 text. So, it was very obvious that interactive reading became the only type of assessing reading used in this exam. Moreover, it only provided 2 tasks in 17 texts. They are the impromptu reading plus comprehension question and ordering tasks. Furthermore, the impromptu reading plus comprehension question became the most dominant task in this type. It covered $98 \%$ of the whole questions. Then, the rest of it was contained with ordering tasks which covered $2 \%$ of the whole questions.

Based on the findings, it shows that Brown's theory was realized on the English national examination for junior high schools in the academic year 2018/2019. Of the four types of assessing reading, there was one type only that was implemented on this exam. It was interactive reading.

The interactive reading was chosen because the students were intended to identify the features of the texts. It was in line with the goals of interactive reading. It was stated by Brown (2004, p.189) that the focus of an interactive task is to identify relevant features (lexical, symbolic, grammatical, and discourse) within texts of moderately short length with the objective of retaining the information that is processed. Thus, the texts used in this type of assessing reading have moderately short length. That is why this type of assessing reading was very suitable for the students of junior high schools. Moreover, the students were also asked to 
know the types of the text genres such as narrative text, descriptive text, procedure text, announcements, letters, advertisement, and the like. The students were asked not only to know the types of the text genres, but also to know the social function of those text genres, the main idea, and expressions in context, grammatical features, detail of the texts, unstated details, supporting ideas, and vocabulary in context. Those could be done only if the students interacted with those texts. Here, the students needed to read several paragraphs of those texts or more and psycho-linguistically interacted with the text (negotiate meaning) to identify relevant features and retain information that was conceptually processed (Brown, 2004). Hence, the students had a combination of form-focused and meaning-focused objectives but with more emphasis on meaning when the process of negotiating meaning occurred.

In addition, the tasks used in this interactive reading were impromptu reading plus comprehension questions. Based on Brown's theory, the tasks of this interactive reading type were the traditional technique that undoubtedly became the oldest and the most common. Further, Brown (2004, p. 204) stated that virtually every proficiency test used this format. Impromptu reading plus comprehension questions became excellent thing because almost all questions in this exam used this type of the tasks. It has some components that are consistent with strategies of effective reading, such as skimming for main idea, scanning for details, guessing for word meanings from context, inference, and using discourse markers. Those became causations why this type of the tasks was very appropriate for the students in the junior high schools. Furthermore, there was a question using an ordering task. The ordering task used in this exam was ordering some words into a good sentence. This type of the task was very good to measure not only the meaning of the sentence but also the grammatical features. Knowing the grammatical features becomes an important thing since English has different grammatical features from Bahasa Indonesia, especially in word orders. That was why this type of the task should be provided in this exam.

Based on the data, it obviously showed that the most dominant type of reading assessment used in this exam was interactive reading. It was obvious since the focus of interactive reading can be the bridge to take the students reach their goals that were to identify relevant features (lexical, symbolic, grammatical, and discourse) within the texts. Further, this type of reading assessment had component that were consistent with strategies of effective reading, such as skimming for main idea, scanning for details, guessing for word meanings from context, inferencing, and using discourse markers. (Brown, 2004, p.204) Those could be the reasons why this type of reading assessment became the most dominant.

However, the other types of assessing reading may be able to be provided in the English national exam. As the students of junior high schools are considered as the language learners in beginner level, selective reading can be an option to be used in the exam. For example, multiple choice (for form focused criteria) can be used to test the students' reading knowledge of vocabulary and grammar. In addition, another task in interactive reading may also be used in this exam which is cloze task. Cloze task is one of the most popular types of reading assessment as it shows the ability to fill in gaps in an incomplete image (visual, auditory or cognitive) and supply (from background schemata) omitted details. (Brown, 2004, p.201).

\section{Conclusions}

Based on the analysis above, it could be stated that Brown's theory of assessing reading were realized on the English national examination for junior high schools in the academic year 2018/2019. Of the four types of assessing reading cited by Brown, it was only found 1 type of assessing reading on this exam. It was interactive reading. Hence, the most dominant type of reading assessment used in this exam was the interactive reading. It consisted of 49 questions of impromptu reading plus comprehension questions and 1 question of ordering tasks. As a 
result, the other types of assessing reading do not come up. Based on this result, it can be underlined that the test makers focused on interactive reading when they created the reading test. Thus, it should be able to be prevented by the teachers at schools to give teaching strategy about interactive reading so that it can help the students improve their reading skill when they do the reading test.

For further studies, it is suggested not to only conduct researches about the strategy to improve the students' reading skill but also to conduct researches about the types of assessing reading that should be known and learnt by the students. By doing this, the students will be easier to do the reading test if they have known about the strategy to do the reading test based on the types of assessing reading.

\section{References}

Ahmada, A. (2020). Using Group Work To Improve Students' Reading Comprehension Skill. Journey (Journal of English Language and Pedagogy),3(1), 14-18. https://doi.org/10.33503/journey.v3i1.714

Al Aziz, E. N., \& Yusanti, G. (2020). Increasing Students' Reading Comprehension Skill By Using Written Text Book. English Education: Journal of English Teaching and Research, 5(2), 179-186. https://doi.org/10.29407/jetar.v5i2.14500

Brown, H. D. (2004). Language assessment: Principles and classroom practices. London, UK: Longman Group UK Ltd.

Celce-Murcia, M. (2001). Teaching English as a Second or Foreign Language. Boston: Heinle \& Heinle.

Elleman, A. M. \& Oslund, E. L. (2019). Reading Comprehension Research: Implications for $\begin{array}{lllll}\text { Practice } & \text { and } & \text { Policy. }\end{array}$ https://doi.org/10.1177\%2F2372732218816339

Goodman, Kenneth. (2012). The reading process. In Carrel, P.L., J. Devine, and D.E. Eskey. Interactive Approaches to Second Language Reading. Cambridge: Cambridge University Press.

Linse, C. T. (2005). Practical English language teaching. Young learners. New York, NY: McGraw-Hill Companies Inc.

Mustafa. (2012). Indonesian People Reading Habit is Very Low [Online]. Retrieved July 29, 2021

from http://consalxv.perpusnas.go.id/uploaded_files/pdf/papers/normal/ID_B_Mustafa- paperreading-habit.pdf

Polit, D. F., \& Hungler, B. P. (1999). Nursing research; Principles and methods (6th ed). Philadelphia, Pennsylvania: Lippincott Willams \& Wilkins.

Putri, A. G., Octavialis, A. N. \& Sadikin, I. S. (2019). Improving Students' Reading Skill Through Collaborative Learning. Project (Professional Journal of English Education), 2(6), 861-868. http://dx.doi.org/10.22460/project.v2i6.p861-868

Republik Indonesia, Peraturan Menteri Pendidikan Nasional Republik Indonesia Nomor 1 Tahun 2005 tentang Ujian Nasional. 
Republik Indonesia, Peraturan Pemerintah Republik Indonesia Nomor 19 Tahun 2005 tentang Standar Nasional Pendidikan.

Republik Indonesia, Undang-Undang Nomor 20 Tahun 2003 tentang Sistem Pendidikan Nasional.

Rijal, S., \& Rohaniyah, J. (2020). Improving Students' Reading Ability On Introduction To Linguistic Class Through Two -Stay Two Stray (Ts-Ts) Technique. English Education: Journal of English Teaching and Research, 5(2), 124-135. https://doi.org/10.29407/jetar.v5i2.14782

Rombot, O., Boeriswati, E., Suparman, M. A. (2020). Improving Reading Comprehension Skills of International Elementary School Students through Blended Learning. Al Ibtida: Jurnal Pendidikan Guru MI, 7(1), 56-68. http://dx.doi.org/10.24235/al.ibtida.snj.v7il.6045

Urquhart, S., \& Weir, C. (1998). Reading in a Second Language: Process, Product and Practice.New York: Longman.

Yuilyana. (2020). Alasan Presiden Jokowi Resmi Hapus Ujian Nasional 2020 [web page]. Retrieved July 29, 2021, from https://www.kompas.tv/article/72920/alasan-presidenjokowi-resmi-hapus-ujian-nasional-2020 